Article

\title{
Conventionalization of Organic Agriculture: A Multiple Case Study Analysis in Brazil and Italy
}

\author{
Oscar José Rover ${ }^{1}$, Adevan da Silva Pugas ${ }^{1}\left(\mathbb{D}\right.$, Bernardo Corrado De Gennaro ${ }^{2}{ }^{(}$, \\ Francesco Vittori ${ }^{3}$ (i) and Luigi Roselli ${ }^{2, *}$ (D) \\ 1 Department of Zootechny and Rural Development, Federal University of Santa Catarina, \\ Florianópolis-SC 88034-001, Brazil; oscar.rover@ufsc.br (O.J.R.); vanpugas@gmail.com (A.d.S.P.) \\ 2 Department of Agricultural and Environmental Science, University of Bari Aldo Moro, 70126 Bari, Italy; \\ bernardocorrado.degennaro@uniba.it \\ 3 Department of Human Sciences, University of Verona, 37129 Verona, Italy; francesco.vittori@univr.it \\ * Correspondence: luigi.roselli@uniba.it; Tel.: +39-0805442883
}

Received: 9 July 2020; Accepted: 12 August 2020; Published: 14 August 2020

\begin{abstract}
The conventionalization of organic agriculture has been described as a process in which organic agriculture increasingly adopts the features of conventional modes of production based on industrial farming methods. The increasing supply of organic products to the large retailers is considered the main driver of conventionalization. This process has negative implications for the agrobiodiversity of organic farming systems. The present study aims to investigate and analyze the impact of retailing strategies on the agrobiodiversity of organic farms. A survey of farms located in rural areas near large urban centers (three metropolitan regions in Southern Brazil and four Italian regions) was undertaken. Data was collected through face-to-face interviews based on a semi-structured questionnaire. The analysis indicates that the farms surveyed maintained a high level of agrobiodiversity and active participation in alternative food networks. Our findings point out that there was a significant and positive correlation between the crop richness index and the share of farm sales through alternative food networks. We conclude that adopting various forms of direct sale is the key factor in stimulating farms' agrobiodiversity, but proximity to densely populated areas is a necessary precondition for the development of the short food supply chains needed to stimulate the diversification of organic agriculture.
\end{abstract}

Keywords: organic farming; agroecology; agrobiodiversity; alternative food networks; marketing channel

\section{Introduction}

Agrobiodiversity is a component of biodiversity and is a key element of agricultural development [1]. A common measurement of agrobiodiversity is the number of species used for agricultural production. The prefix "agro" draws attention to the relationship between these species and agricultural production. These can be domesticated and cultivated species, wild species that interact somehow with domesticated species or species in the process of domestication [2].

Biodiversity, as well as agrobiodiversity and agroecology, are concepts relating to the environmental issues involved in farming activities, but are also linked to traditional knowledge and modes of social organization [3]. Environmental studies have demonstrated the loss of agrobiodiversity due to the spread of the so-called industrial agriculture paradigm [4]. This type of agriculture aims to increase efficiency by focusing production on a reduced number of species and varieties (crop specialization), which narrows the genetic base of agriculture $[5,6]$. Furthermore, traditional varieties are replaced with "modern" varieties, aiming to thus maximize productivity [7]. 
Agroecology is an alternative paradigm aiming to solve actual challenges of agricultural production. From its birth (in the 1930s), the term agroecology acquired different meanings, i.e., scientific discipline, agricultural practice, political or social movement. Further, various investigation approaches have been developed, ranging from plot and field scales to agroecosystem and farm scales, or even covering the whole food system [8]. In this study, we consider agroecology as an alternative farming paradigm, which is based on enhancing agrobiodiversity. It involves the quantitative increase of species interacting within agroecosystems, aiming to improve the stability of the farming system [9]. From this perspective, a high level of agrobiodiversity is a key feature of agroecology, where a high level of trophic interaction in the agroecosystem promotes species' self-regulation, including species regarded by industrial agricultural as pests and pathogens [9-12].

The agroecological paradigm has been boosted by the alternative agriculture movements born in the 1960s [8,13]. Actually, agroecological farming is not market-driven, given that no certification systems nor labels exist so far for the produce. On the contrary, organic farming is a specific agroecological paradigm that has been recognized in laws, which codify the overall principles, the restrictions for the production process, the certification procedures and the conditions to access to markets $[14,15]$. From the 1990s, governmental regulation of organic farming at the international level has bolstered this agroecological paradigm. Indeed, the recognition in law of organic farming has allowed the commercialization of organic products at a higher price than conventional ones [16,17]. Driven by environmental concerns, health awareness, and interest in quality and local provenance $[18,19]$, consumers are willing to pay a premium price for organic products.

According to the International Federation of Organic Agriculture Movements (IFOAM-Organics International) organic agriculture is "a production system that sustains the health of soils, ecosystems, and people. It relies on ecological processes, biodiversity and cycles adapted to local conditions, rather than the use of inputs with adverse effects. Organic agriculture combines tradition, innovation and science to benefit the shared environment and promote fair relationships and good quality of life for all involved internationally" [20]. According to international standards, organic products are obtained by farming systems that exclude the use of pesticides, synthetic fertilizers, transgenic seeds and ionizing radiation. Organic producers use a set of alternative production inputs, bought either on the market or produced on the farm (e.g., manure from livestock).

The increasing demand for organic food is due to consumers' growing awareness of health and environmental issues related to food production and consumption [21]. Following the extraordinary growth of the organic market, some studies have however drawn attention to the weakening of the original principles of organic farming and agroecology, a phenomenon labeled as the "conventionalization" of organic farming [22-29].

The conventionalization thesis refers to the process by which organic farming increasingly shares the same basic features as conventional production [30]. Darnhofer et al. [31] argue that the shift of organic farming toward conventionalization is unquestionable. Some authors [31,32] have argued, however, that the debate over the development of organic farming should focus on understanding its fundamental principles and values, rather than contrasting "real" and "conventionalized" organic agriculture.

As a result, empirical analyses are needed to test the conventionalization of organic agriculture, taking into account territorial contexts (e.g., proximity of organic farms to urban areas) as well as the organization of supply chains and retailing strategies.

The spread of organic food to large retailers is considered the main driver of conventionalization. The steady increase of consumers' interest in organic food has attracted the interest of large retailing companies, transforming this product into a profitable market segment $[9,10]$. They have also promoted several changes along the supply chain [11]. In response to large retailers' growing demand, many conventional producers have adopted organic standards, but they have also neglected the principles of alternative agriculture that agroecology seeks to advance [33]. 
The present study aims to analyze the impact of marketing strategies adopted by organic producers on their farms' agrobiodiversity. The rest of the manuscript is structured into four sections. The first presents emerging issues about the conventionalization of organic agriculture. The second section describes the methods adopted. The third presents and discusses the empirical results. Finally, the main conclusions of the study are drawn.

\section{Literature Review on Conventionalization of Organic Agriculture}

The conventionalization thesis points to the tendency to weaken the agroecological principles underlying the organic production system. This is a consequence of large companies entering all stages of the organic supply chain (from farming to retailing), shifting the paradigm toward economies of scale and so reducing agrobiodiversity $[22,24,25]$. This trend is led by large-scale retailers, which has encouraged highly capitalized companies to enter the organic sector [30]. In recent years, many of the leading corporations in the conventional agri-food system have entered the organic market, replicating the same features of the conventional market, where farmers become price-takers and are required to conform to manufacturers' and retailers' quality standards $[34,35]$.

In addition to growing and profitable demand, the global spread of organic certification standards is a powerful driver of big agri-food business groups' entry [22,24]. The establishment of certification standards has encouraged many conventional producers to convert to organic farming by simply replacing conventional inputs with substances allowed by organic method. Certification costs also are more easily afforded by large and well-capitalized companies, so discouraging small-scale and family farmers from entering the organic food supply chain [30].

A conventionalized organic production system is characterized by mechanized monocultures, employment of wagered labor, regional specialization and vertical integration with agri-industries by means of contracts [22,24]. This reproduces the features of conventional agri-food globalization and the industrialization of agriculture [35].

The pioneering study of conventionalization focused on organic vegetable markets in California and two types of supply chain: the first one was under the control of large companies and pursued higher yields; the second one consisted of marginal producers who relied on alternative distribution channels as the primary source for the socio-economic reproduction of their livelihood [22].

The debate around conventionalization has focused on the capacity of large manufacturing companies and large retailers to totally dominate the organic market and so affect the social, environmental and economic ideals associated with organic farming [24]. This entails the distancing of conventionalized organic agriculture from the principles of agroecology, as well as the separation of alternative agriculture movements from more industrialized modes of production [34].

This theoretical proposition has been severely criticized, especially because its generalizations are at odds with the complexities that various empirical studies evince $[30,36,37]$. Nevertheless, the debate remains important, mainly due to the increasing spread of organic products within conventional retailing chains and the tendency to subordinate farmers (when they are not excluded) to retailers' and processors' purchasing requirement [38-40].

Large farms can reduce prices to levels that small-scale farms cannot meet, by increasing the employment of technology and scaling up production [41]. Such a process sidelines products derived from family farming, socio-biodiversity and local producer organizations, and has an adverse impact on less capitalized and competitive areas of production [24]. Other key features of this trend are the quality and quantities of product that retail networks demand, as well as their power to impose rules on producers. This market pressure pushes organic farmers to reduce their attention to social and ecological principles, and to adopt more conventional orientations [22,24,41].

From a technological perspective, conventionalization induces the production system to deviate from an agroecological approach that is oriented toward reshaping agroecosystems and promoting functional biodiversity [7]. The different biotic components of the productive processes 
within agroecosystems are replaced by inputs produced outside the production site, rendering the agroecosystems dependent on external inputs [12].

In this perspective, the productive units (i.e. The farm) tend to intensify their production systems, specializing in the more profitable crops. Specialization, coupled with the adoption of external inputs allowed in organic agriculture and produced by specialized companies, reduces biodiversity and limits the biological control operated by trophic interactions within the agroecosystem [11].

The greater the diversity of cultivated species, the greater is the complexity of agroecosystems $[5,6]$, and, consequently, the closer production accords with agroecological principles. Simplified organic agroecosystems, characterized by lowered diversity and complexity, tend to estrange themselves from these principles and converge on a sort of "conventional organic agriculture" [9]. Therefore, by analyzing farms' agrobiodiversity and retailing strategies, it is possible to test whether there is a tendency toward conventionalization [11,12].

\section{Materials and Methods}

A multiple case study analysis [42] was undertaken, surveying Brazilian and Italian farms located in densely populated regions. The Brazilian case study considered farms located in the areas surrounding Curitiba (Paraná), Florianopolis (Santa Catarina) and Porto Alegre (Rio Grande do Sul). The Italian case study included farms located around densely populated cities of four administrative regions, namely Lombardia, Marche, Abruzzo and Puglia. Both surveyed areas were selected because of their proximity to large centers of consumption and the presence of alternative food networks (e.g., farmers' markets, collective purchasing groups, etc.) [40].

The investigation of these sites was carried out by adopting a qualitative approach through semi-structured interviews with organic farmers. The semi-structured interviews sought to elicit information about: (1) farmers' motivations for their conversion to organic method; (2) factors considered when choosing the cropping system; (3) type and share of sales through each marketing channel accessed by farmers; (4) number of species and varieties grown on the farm; (5) farmers' perceptions of agrobiodiversity on their farm; (6) and identification of management practices promoting their farms' agrobiodiversity.

The sample was selected by drawing on the expertise of key informants in local universities and research institutes, in public and private organizations linked to organic farming (e.g., government agencies, private initiatives and citizens' associations), in organizations of technical assistance, and in social movement organizations.

Farmers to be interviewed were selected according to three criteria: (i) time elapsed since conversion to organic farming, (ii) dimensions of the farm (utilized agricultural area or UAA), and (iii) crop specialization (distinguishing between crops destined for fresh food markets and crops for food processing) (Table 1). These three criteria were employed to obtain the widest possible diversity within the sample.

Table 1. Sample selection criteria applied in each country.

\begin{tabular}{|c|c|}
\hline Criterion & Description \\
\hline $\begin{array}{l}\text { (i) time elapsed since conversion to } \\
\text { organic farming }{ }^{*} \text {. }\end{array}$ & $\begin{array}{c}\text { We distinguished between "pioneer farmers" who adopted organic farming } \\
\text { before the introduction of the national legal framework and "new farmers" who } \\
\text { started organic farming after that date. }\end{array}$ \\
\hline (ii) dimensions of the farm (UAA) ${ }^{* *}$ & $\begin{array}{l}\text { We distinguished between small and large farmers, considering as reference } \\
\text { dimension the average size of organic farms at national level. }\end{array}$ \\
\hline (iii) crop specialization & $\begin{array}{l}\text { We distinguished between farms mostly oriented to crops destined for fresh food } \\
\text { markets and farms mostly oriented to crops destined for food processing. }\end{array}$ \\
\hline \multicolumn{2}{|c|}{$\begin{array}{l}\text { "In Brazil, the legal framework of organic farming was established in } 1999 \text { (Normative Instruction } 07 \text { of } 17 \text { May 1999). } \\
\text { In Italy, as well in the European Union, the organic standard was introduced in } 1991 \text { (Council Regulation (EEC) No. } \\
\text { 2092/91 of } 24 \text { June 1991). ** According to the latest Italian general agriculture census (2010), average UAA on Italian } \\
\text { organic farms was } 18 \text { hectares [43]. In Brazil, according to data published by "Cadastro Nacional de Produtores } \\
\text { Orgânicos" (2015), the average size was } 85 \text { hectares [44]. Source: Own elaboration (2016). }\end{array}$} \\
\hline
\end{tabular}


The data collected were organized in spreadsheets, and then systematized and analyzed using descriptive statistics [45,46]. The information obtained through open questions was categorized, using content analysis [47]. Finally, Spearman rank-order correlation analysis was performed to ascertain if there was a statistical association between farm agrobiodiversity and retailing strategy.

Data collection complied with national ethical requirements. In particular, all farmers gave their informed consent to participate in the study and all data were collected anonymously. All data were also recorded and managed in accordance with the "Italian Personal Data Protection Code" (Law Decree no. 196 of 30 June 2003).

\section{Results and Discussion}

The survey involved 48 farms, 24 in Brazil and 24 in Italy (Table 2). Data collection in Brazil was performed in 2017, interviewing farmers located in the area surrounding each of three capital cities of southern regions, namely Curitiba (Paraná), Florianopolis (Santa Catarina) and Porto Alegre (Rio Grande do Sul). In Italy, the survey took place in 2016, interviewing nine farmers from the administrative region of Puglia, seven from Lombardia, four from Abruzzo and four more from the Marche region.

Table 2. Main statistics of the sample.

\begin{tabular}{ccccc}
\hline & \multicolumn{2}{c}{$\begin{array}{c}\text { Brazil } \\
\text { (No. of Farms: 24) }\end{array}$} & \multicolumn{2}{c}{$\begin{array}{c}\text { Italy } \\
\text { (No. of Farms: 24) }\end{array}$} \\
\cline { 2 - 5 } $\begin{array}{c}\text { Sample } \\
\text { Distribution }\end{array}$ & $\begin{array}{c}\text { Time Elapsed } \\
\text { since Conversion } \\
\text { to Organic (years) }\end{array}$ & $\begin{array}{c}\text { Farms' } \\
\text { Dimensions UAA } \\
\text { (ha) }\end{array}$ & $\begin{array}{c}\text { Time Elapsed } \\
\text { since Conversion } \\
\text { to Organic (years) }\end{array}$ & $\begin{array}{c}\text { Farms' } \\
\text { Dimensions UAA } \\
\text { (ha) }\end{array}$ \\
\hline 1st quartile & 9.00 & 3.30 & 8.50 & 5.00 \\
2nd quartile & 14.00 & 6.10 & 15.50 & 17.00 \\
3rd quartile & 20.00 & 15.00 & 25.50 & 34.00 \\
Mean & 14.21 & 24.72 & 19.79 & 43.54 \\
St. dev. & 7.29 & 53.57 & 18.25 & 64.86 \\
\hline
\end{tabular}

Source: Own elaboration (2020).

\subsection{Farmers' Motives for Conversion to Organic Farming}

A wide variety of reasons has driven farmers to adopt organic farming (Figure 1). The main reason among Brazilian farmers was the health problems of farmers' families caused by the use of pesticides, highlighting a certain trauma of producers caused by the usage of conventional inputs. Among Italian farmers, the most common reason given was instead related to the environmental consequences of the dominant agricultural system. In both countries, there are farmers who point to market opportunities as one of their main reasons for converting to organic farming. Economic motives are reported in other studies as influencing the choice to convert to organic farming [21]. This last choice can drive production toward either the expansion or the reduction of agrobiodiversity. 


\begin{tabular}{|c|c|c|c|c|c|c|c|c|c|c|c|c|c|}
\hline & \multicolumn{12}{|c|}{ No. of farmers } \\
\hline & & 2 & 4 & 6 & 8 & 10 & 12 & 14 & 16 & 18 & & & $2 \quad 24$ \\
\hline \multirow{8}{*}{ 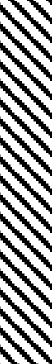 } & Worries about the usage of pesticides & $m w$ & $w$ & $\omega$ & $M$ & W & $w \infty$ & 13 & & & & & \\
\hline & Market opportunity & wwo & W & $W$ & & $\omega$ & 11 & & & & & & \\
\hline & Alternative life style & wow & wo & wo & W & w & & & & & & & \\
\hline & Environmental worries & was & w & 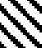 & 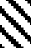 & & & & & & & & \\
\hline & Health worries & Now & wo & s & & & & & & & & & \\
\hline & Family worries & $m_{\infty}$ & s & & & & & & & & & & \\
\hline & Movements and organizations influence & Wwo & & & & & & & & & & & \\
\hline & Other motivations & Ww 2 & & & & & & & & & & & \\
\hline \multirow{8}{*}{$\stackrel{\vec{\Xi}}{\underline{A}}$} & Environmental worries & wo & 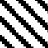 & & & & $N_{N}$ & & & \$ & 18 & & \\
\hline & Health worries & wow & w) & s) & 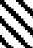 & $\$$ & & & & & & & \\
\hline & Market opportunity & ww: & $w$ & $\$$ & 7 & & & & & & & & \\
\hline & Worries about the usage of pesticides & Wwo & W & & & & & & & & & & \\
\hline & Alternative life style & Wwo & 3 & & & & & & & & & & \\
\hline & Public subsidies & wow & & & & & & & & & & & \\
\hline & Soil fertility maintenance & $\$ 1$ & & & & & & & & & & & \\
\hline & Other motivations & $\$ 1$ & & & & & & & & & & & \\
\hline
\end{tabular}

Figure 1. Main motivations that have boosted the conversion to organic farming. Source: Own elaboration (2020). Each farmer could choose one or more options.

\subsection{Main Drivers of Farmers' Choices about Cropping System}

The main drivers of farmers' decisions about what and how much to produce were sought (Figure 2). In the Brazilian case, the five main factors cited were: (i) customers' requests (cited by 79\% of respondents); (ii) adaptation to changing climatic conditions (42\%); (iii) increasing farm productivity (21\%); (iv) satisfying food needs of the family (12\%); (v) reducing the manpower employed on the farm ( $8 \%$ ). In the Italian case, the following issues were identified: (i) customers' requests (cited by $63 \%$ of respondents); (ii) adaptation to changing climatic conditions (58\%); (iii) family or local farming tradition (46\%); (iv) increasing farm productivity (21\%); (v) reducing the manpower employed on the farm $(13 \%)$. These data convey the key role of customers' requests in determining production choice.

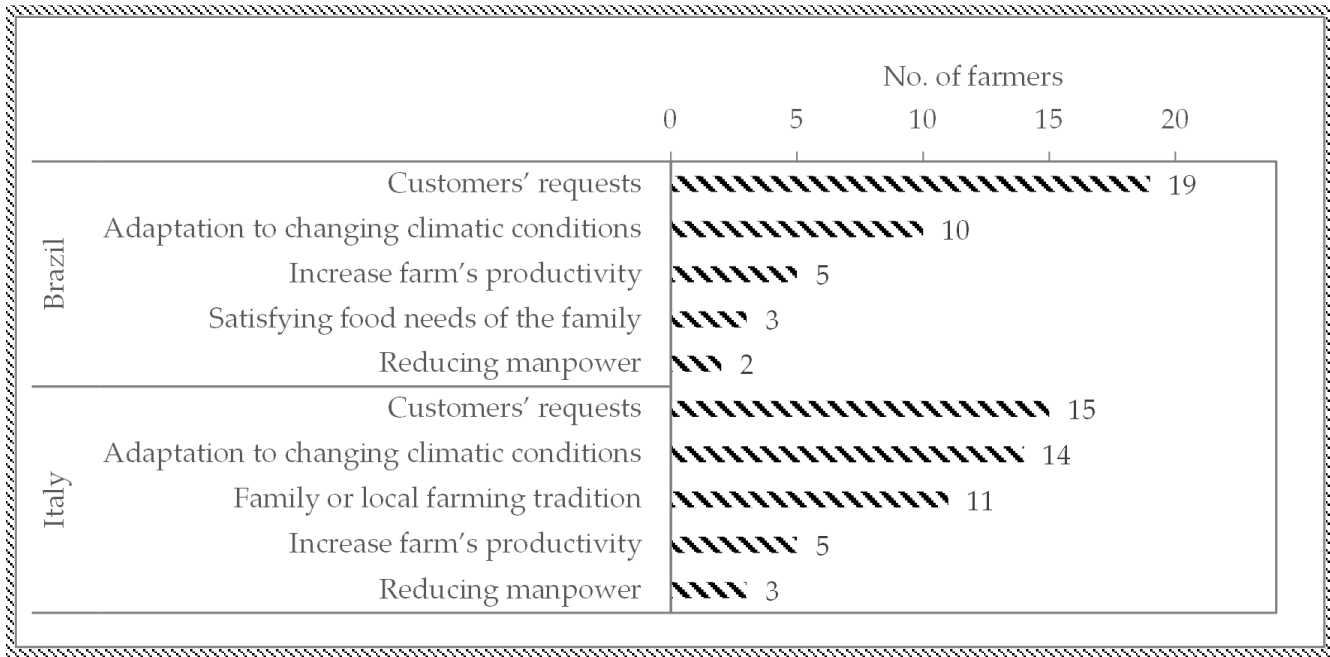

Figure 2. Main drivers of farmers' choices about cropping system. Source: Own elaboration (2020). Each farmer could choose one or more options. 


\subsection{Main Marketing Channel Accessed by Organic Farmers}

In both the cases investigated, market demand was farmers' reason to adopt organic production methods and determined their decisions with respect to production. It is therefore useful to examine the marketing channels most commonly accessed by the farmers surveyed.

Table 3 shows the distribution channels accessed by farmers in the two case study sites. For each marketing channel, the table reports the number of farmers accessing the channel and the average percentage of product sold through the same channel. Marketing channels were grouped in two main categories, identified according to Renting et al. [48]: (i) alternative food networks, and (ii) conventional food supply chain. At both sites, farmers have predominantly accessed AFNs (22 out of 24 farmers in Brazil, 22 out of 24 farmers in Italy). In fact, participating in an AFN is a key marketing strategy followed by small farmers to obtain a fairer income [49]. Through the AFNs, "the producer delivers the goods with his own hands to the consumer" [50] (p. 6), thus enabling a direct relationship between producers and consumers. In addition, this direct relationship provides farmers with an opportunity to understand consumers' expectations with regard to both product quality and the products sought. Finally, the relationship can affect farms' agrobiodiversity. Productive diversification is driven by farmers as a way to ensure the variety of products they can deliver, so attracting customers' loyalty [51].

Following Buainain and Batalha [16], the choice of the marketing strategy depends on factors such as the scale of production, logistical infrastructure, continuity of delivery, as well as other factors relating to farmers' ideological preferences.

Despite the proximity of the surveyed farms to consumption centers/areas favoring access to AFNs, most of farmers accessed both type of sales channels, i.e., alternative food networks (AFNs) and conventional supply chain (CSC) (Figure 3). However, AFNs represent the most relevant choice in both Brazil and Italy, accounting for 22 out of 24 farms and $64 \%$ average share of sales in the first case, and 22 out of 24 farms and $60 \%$ average share of sales in the second (Table 3).

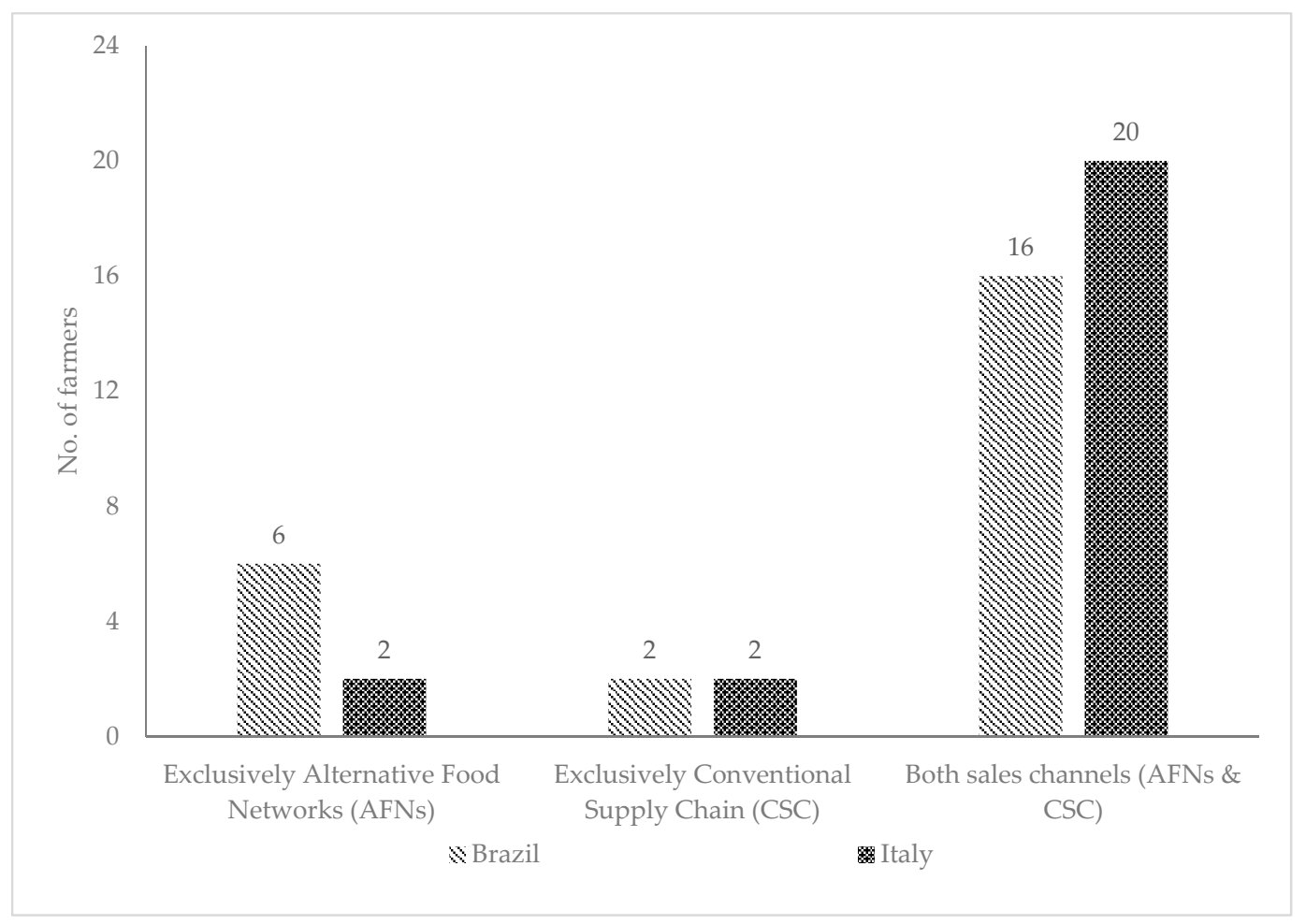

Figure 3. Sales channels accessed by farmers. Source: Own elaboration (2020). 
Table 3. Sales channels accessed by farmers and average share of sales *.

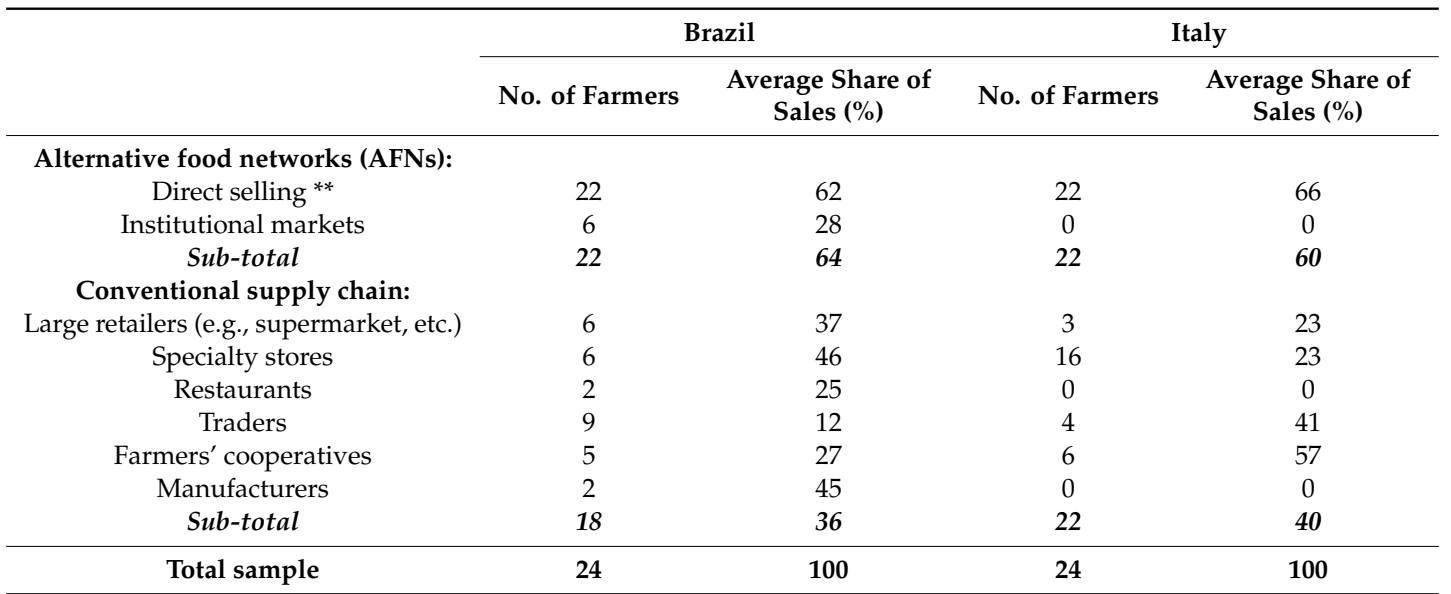

Source: Own elaboration (2020). * Each farmer could choose one or more options. ${ }^{* *}$ It includes farmers' markets, collective purchasing groups, home delivery systems and other forms of direct sale. Farmers' markets are the main form of direct sale in Brazil, while collective purchasing groups are the main form of direct selling in Italy.

Determinants for farmer participation in AFNs have been analyzed in the literature, encompassing economic, social and environmental motivations [52,53]. According to Corsi and Mazzocchi [52], the main drivers of participation in AFNs are agricultural factors related to structural characteristics of the agricultural sector (e.g., farm's dimension, farmer's age and level of education) as well as the farmer's adoption of quality certification schemes (organic, geographical indications). Further, some territorial factors were found to influence the participation in AFNs (e.g., income and age of the local population). Moreover, Migliore et al. [53] identified through a behavioral approach two main types of farmers that participate in AFNs: (i) farmers closer to commercial entrepreneurs mostly oriented toward profit maximization; (ii) farmers closer to social entrepreneurs mostly oriented towards satisfying social and environmental needs.

\subsection{Agrobiodiversity in Organic Farms}

The AFNs are the most important retailing channel accessed by the farmers surveyed. Hence, it is worth examining whether this form of sale impacts on farm agrobiodiversity. The following variables were collected for each farm: the number of crops and the number of varieties grown, and the utilized agricultural area (UAA). In addition, the crop richness index (CRI) was calculated for each farm by considering the number of species produced per hectare of UAA [54]. The sample statistics are shown in Table 4. Brazilian farmers grow, on average, 24 species and 43 varieties destined for sale. The distribution of farms according to number of cultivated crops shows that in the first quartile $(25 \%$ of the sample) they grow up to three species. Farms in the second quartile cultivate between 3 and 20 species, and in the third quartile between 20 and 35 species. The farms in fourth quartile grow the highest number of species, i.e., between 35 and 69 .

On the Italian farms surveyed, the number of species and varieties produced for commercialization is lower than on their Brazilian counterparts' farms. Italian farmers cultivate, on average, 13 species and 24 varieties. Furthermore, the distribution of Italian farms according to the number of crops cultivated confirms that agrobiodiversity is lower than that found on the Brazilian farms.

While the average size of Italian farms is almost double that found in Brazil, the CRI is much higher in Brazil than in Italy, amounting respectively to 6.696 and 0.939 . This difference in the CRI index reveals the different complexity of cropping system in the two countries. 
Table 4. Agrobiodiversity in the surveyed farms.

\begin{tabular}{|c|c|c|c|c|c|c|c|c|}
\hline \multirow[b]{3}{*}{$\begin{array}{c}\text { Sample } \\
\text { Distribution: }\end{array}$} & \multicolumn{5}{|c|}{ Brazil } & \multicolumn{3}{|c|}{ Italy } \\
\hline & \multicolumn{2}{|c|}{ Crops Grown } & \multirow{2}{*}{$\begin{array}{l}\text { UAA } \\
\text { (ha) }\end{array}$} & \multirow[b]{2}{*}{ CRI } & \multicolumn{2}{|c|}{ Crops Grown } & \multirow{2}{*}{$\begin{array}{l}\text { UAA } \\
\text { (ha) }\end{array}$} & \multirow[b]{2}{*}{ CRI } \\
\hline & Species N. & Varieties N. & & & Species N. & Varieties N. & & \\
\hline 1st quartile & 3.00 & 9.00 & 3.30 & 0.500 & 2.00 & 5.00 & 5.00 & 0.120 \\
\hline 2nd quartile & 20.00 & 45.00 & 6.10 & 2.272 & 6.00 & 15.00 & 17.00 & 0.350 \\
\hline 3rd quartile & 35.00 & 60.00 & 15.00 & 6.557 & 15.00 & 32.00 & 34.00 & 1.000 \\
\hline Min & 1.00 & 2.00 & 1.00 & 0.005 & 1.000 & 1.00 & 1.00 & 0.020 \\
\hline Max & 69.00 & 100.00 & 220.00 & 50.000 & 50.00 & 80.00 & 268.00 & 5.000 \\
\hline Mean & 23.88 & 42.79 & 24.72 & 6.696 & 12.63 & 23.71 & 43.54 & 0.939 \\
\hline St. dev. & 20.46 & 33.21 & 53.57 & 11.089 & 14.01 & 80.00 & 64.86 & 5.000 \\
\hline
\end{tabular}

\subsection{Relationship Between Farm's Agrobiodiversity and Selling Strategy}

The data collected in the two case study sites were analyzed to test the hypothesis of a positive relationship between farm agrobiodiversity and sales strategy. Specifically, a Spearman rank-order correlation coefficient $(\rho)$ [55] was employed to measure the association between each measurement of agrobiodiversity (i.e., number of species grown, number of varieties grown, CRI) and the share of sales through AFNs (percentage of total turnover).

The Spearman rank-order correlation coefficients between all three measurements of agrobiodiversity and the share of sale through AFNs are positive and significant ( $p$-value $<0.05$ ), ranging between 0.296 and 0.329 (Table 5). We can therefore conclude that the higher a farm's agrobiodiversity, the higher its share of sales through AFNs.

Table 5. Association analysis between farm's agrobiodiversity and accessing AFNs.

\begin{tabular}{cccc}
\hline & $\begin{array}{c}\text { N. Species vs. } \\
\text { AFNs_share }\end{array}$ & $\begin{array}{c}\text { N. of Varieties vs. } \\
\text { AFNs_share }\end{array}$ & $\begin{array}{c}\text { CRI vs. } \\
\text { AFNs_share }\end{array}$ \\
\hline Number of obs & 48 & 48 & 48 \\
Spearman's rho $(\rho)$ & 0.296 & 0.320 & 0.329 \\
Prob $>$ t & 0.0414 & 0.0265 & 0.0225 \\
\hline
\end{tabular}

\subsection{Farmers' Perceived Change of Farm Agrobiodiversity}

Farmers' self-evaluation of farm agrobiodiversity since their conversion to organic farming was assessed. In particular, producers were asked to assess if the commercial agrobiodiversity (i.e., the number of species grown for sale) and general agrobiodiversity (i.e., the number of species grown for family food, green manure and biological control) had changed with reference to their own farm.

Most of the farmers, on both sites, reported growth in the number of species grown and/or those naturally present on their farms over the period from first conversion to organic farming to the time of survey. Furthermore, a majority of farmers observed no reduction of biodiversity (Figure 4). In detail, agrobiodiversity has increased or remained steady, independently of farming scale or length of involvement in organic farming.

These findings confirm the relevance of market demand to the management of organic farms. Due to the influence exerted by market demand, those producers accessing alternative forms of distribution have favored the diversification of production through the cultivation of many species and varieties. The strategy of marketing by direct sale has attracted consumers' trust and loyalty, based on both price and quality [51]. 


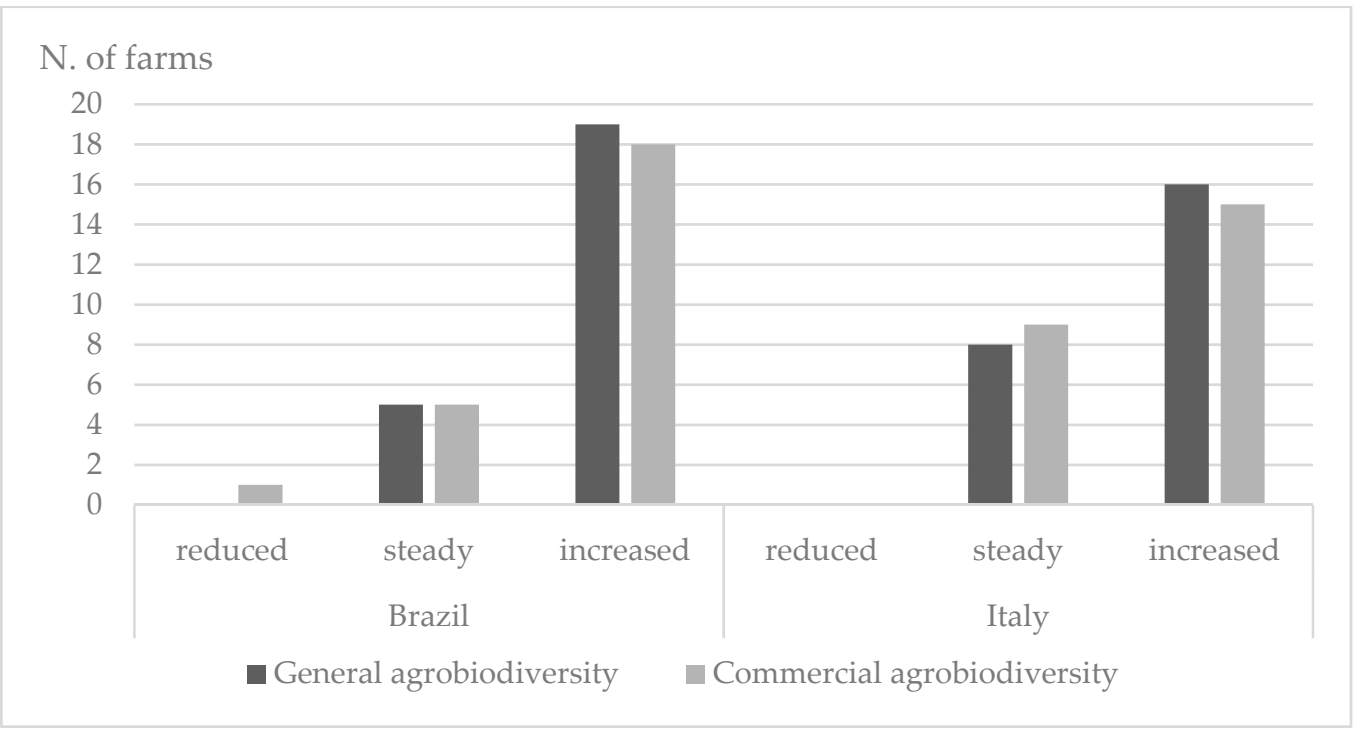

Figure 4. Farmers' perceived variation in the agrobiodiversity (general and commercial) of their own organic farms over time. Source: Own elaboration (2020).

\subsection{Management Practices Promoting the Increase of Farm Agrobiodiversity}

The tendency to increase agrobiodiversity in the organic farms examined is confirmed by the findings relating to agricultural practices. In both contexts, diverse practices connected to the promotion of biodiversity were in use (Figure 5). Practices such as green fertilizing, crop rotation and the use of organic composting have been widely used by most Brazilian and Italian farmers. Management systems organized around the use of such techniques favor the increase of ecological interactions in the agroecosystem, as is advocated by the principles of agroecology.

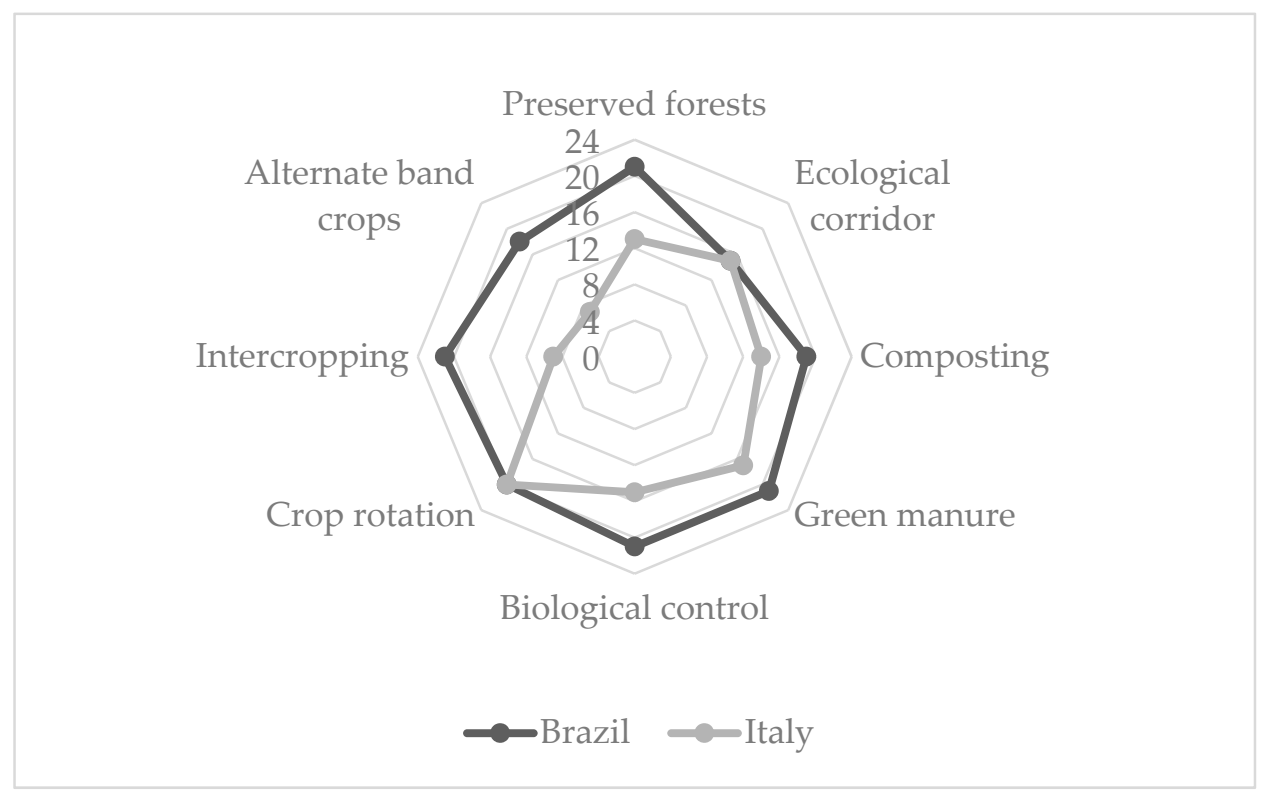

Figure 5. Number of farmers adopting farming practices boosting agrobiodiversity. Source: Own elaboration (2020).

\section{Conclusions}

The findings of the present study confirm that organic farms oriented toward sale through direct distribution channels are driven to satisfy consumers' emerging needs and do so without 
hindering the maintenance or even the growth of biological and agricultural biodiversity. The thesis of conventionalization in organic agriculture $[22,24,25]$ is not confirmed by the two case studies. In particular, direct sale and spatial proximity to large consumption centers are key to fostering biodiversity on the organic farms under investigation.

In recent decades, the growing demand for organic food has favored the growth of AFNs [48], based on the spatial and relational proximity between producers and consumers, as well as a dialogical and trust-based relationships between the two parties. We conclude therefore that organic agriculture carried out near urban centers and densely populated regions promotes the development of alternative food networks. This, in turn, stimulates farming diversification and alignment with the founding principles of agroecology $[7,13]$.

The findings are not definitive, however, since there are some limitations. The first is due to a case study approach based on a small and unrepresentative sample. Further studies of larger and more representative samples, controlling for the types of farming or cropping systems, and including organic farms located far from densely populated areas, are needed to verify the thesis of conventionalization. Finally, it would be worthwhile to widen the theoretical approach considering the agroecological transition theory [56,57], in order to deepen the socio-technical lock-in hindering crop diversification.

Author Contributions: Conceptualization, O.J.R., B.C.D.G., A.d.S.P.; methodology, O.J.R., A.d.S.P., L.R.; data survey, O.J.R., A.d.S.P; formal analysis, O.J.R., A.d.S.P., B.C.D.G., L.R.; writing-original draft preparation, O.J.R., A.d.S.P., B.C.D.G., F.V., L.R.; writing-review and editing, L.R.; visualization, L.R.; supervision, O.J.R., B.C.D.G. All authors have read and agreed to the published version of the manuscript.

Funding: This research received no external funding.

Acknowledgments: The authors are grateful to the Coordination for the Improvement of Higher Education Personnel (CAPES)-Brazil.

Conflicts of Interest: The authors declare no conflict of interest.

\section{References}

1. Thrupp, L.A. Linking agricultural biodiversity and food security: The valuable role of agrobiodiversity for sustainable agriculture. Int. Aff. 2000, 76, 283-297. [CrossRef] [PubMed]

2. Santilli, J. Agrobiodiversidade e Direitos Dos Agricultores; Editora Peirópolis: São Paulo, Brazil, 2009.

3. Machado, A.T.; Santilli, J.; Magalhães, R. A Agrobiodiversidade Com Enfoque Agroecológico: Implicações Conceituais e Jurídicas; Embrapa Informação Tecnológica: Brasília, Brazil, 2008.

4. Frison, E.A. From Uniformity to Diversity: A Paradigm Shift from Industrial Agriculture to Diversified Agroecological Systems; IPES-Food: Brussels, Belgium, 2016.

5. Altieri, M. Agroecologia: Bases Cientificas Para uma Agricultura Sustentável, 3rd ed.; Expressão Popular/AS-PTA: São Paulo, Brazil, 2012.

6. Gliessman, S.R. Agroecologia: Processos Ecológicos em Agricultura Sustentável, 4th ed.; UFRGS: Porto Alegre, Brazil, 2009.

7. Nicholls, C.I.; Altieri, M.A.; Vázquez, L.L. Agroecología: Principios para la conversión y el rediseño de sistemas agrícolas. Agroecología 2015, 10, 61-72.

8. Wezel, A.; Bellon, S.; Doré, T.; Francis, C.; Vallod, D.; David, C. Agroecology as a science, a movement and a practice. A review. Agron. Sustain. Dev. 2009, 29, 503-515. [CrossRef]

9. De Assis, R.L.; Romeiro, A.R. Agroecologia e agricultura orgânica: Controvérsias e tendências. Desenvolv. E Meio Ambiente 2002, 6, 67-80. [CrossRef]

10. Abreu, L.S.; Bellon, S.; Brandenburg, A.; Ollivier, G.; Lamine, C.; Darolt, M.R.; Aventurier, P. Relações entre agricultura orgânica e agroecologia: Desafios atuais em torno dos princípios da agroecologia. Desenvolv. Meio Ambiente 2012, 26, 143-160. [CrossRef]

11. Altieri, M.A.; Nicholls, C.I. Agroecology and the Search for a Truly Sustainable Agriculture, 1st ed.; United Nations Environmental Programme, Environmental Training Network for Latin America and the Caribbean: Mexico D.F., Mexico, 2005.

12. Rosset, P.M.; Altieri, M.A. Agroecology versus input substitution: A fundamental contradiction of sustainable agriculture. Soc. Nat. Res. 1997, 10, 283-295. [CrossRef] 
13. Jesus, E.L.D. Diferentes abordagens de agricultura não-convencional: História e filosofia. In Agroecologia Princípios e Técnicas para uma Agricultura Orgânica Sustentável; Aquino, A.M., de Assis, R.L., Eds.; Embrapa Informação Tecnológica: Brasília, Brazil, 2005; pp. 21-45.

14. Migliorini, P.; Wezel, A. Converging and diverging principles and practices of organic agriculture regulations and agroecology. A review. Agron. Sustain. Dev. 2017, 37, 63. [CrossRef]

15. Seufert, V.; Ramankutty, N.; Mayerhofer, T. What is this thing called organic?-How organic farming is codified in regulations. Food Policy 2017, 68, 10-20. [CrossRef]

16. Buainain, A.M.; Batalha, M.O. Séries Agronegócios. Cadeia Produtiva de Produtos Orgânicos; MAPA: Brasília, Brazil, 2007; Volume 5.

17. Souza, M.C.M.D. Produtos orgânicos. In Economia e Gestão dos Negócios Agroalimentare; Zylbersztajn, D., Neves, M.F., Nassar, A.M., Eds.; Pioneira: São Paulo, Brazil, 2000; pp. 385-402.

18. Katt, F.; Meixner, O. A systematic review of drivers influencing consumer willingness to pay for organic food. Trends. Food Sci. Technol. 2020, 100, 374-388. [CrossRef]

19. Rizzo, G.; Borrello, M.; Dara Guccione, G.; Schifani, G.; Cembalo, L. Organic food consumption: The relevance of the health attribute. Sustainability 2020, 12, 595. [CrossRef]

20. IFOAM-Organics International. Available online: https://www.ifoam.bio/ (accessed on 22 January 2020).

21. Brandenburg, A.; Lamine, C.; Darolt, M. Institucionalização do movimento ecológico na agricultura: Mercado e reorganização dos atores sociais. Estud. Soc. Agric. 2013, 21, 221-247.

22. Buck, D.; Getz, C.; Guthman, J. From farm to table: The organic vegetable commodity chain of northern California. Sociol. Rural. 1997, 37, 3-20. [CrossRef]

23. Goldberger, J.R. Conventionalization, civic engagement, and the sustainability of organic agriculture. J. Rural. Stud. 2011, 27, 288-296. [CrossRef]

24. Guthman, J. The trouble with 'organic lite'in California: A rejoinder to the 'conventionalisation'debate. Sociol. Rural. 2004, 44, 301-316. [CrossRef]

25. Pollan, M.O. Dilema do Onívoro: Uma história natural de quatro refeições, 1st Edição; Intrínseca: Rio de Janeiro, Brazil, 2007.

26. Glin, L.C.; Mol, A.P.; Oosterveer, P. Conventionalization of the organic sesame network from Burkina Faso: Shrinking into mainstream. Agric. Hum. Values 2013, 30, 539-554. [CrossRef]

27. Petit, C.; Aubry, C. Typology of organic management styles in a cash-crop region using a multi-criteria method. Org. Agric. 2016, 6, 155-169. [CrossRef]

28. Parra, F.A.C.M.; Norder, L.A.C.; Jovchelevich, P.; Kinjo, S. A convencionalização na produção de sementes na agricultura orgânica brasileira. Rev. Econ. Sociol. Rural 2018, 56, 565-582. [CrossRef]

29. Fouilleux, E.; Loconto, A. Voluntary standards, certification, and accreditation in the global organic agriculture field: A tripartite model of techno-politics. Agric. Hum. Values 2017, 34, 1-14. [CrossRef]

30. Constance, D.H.; Choi, J.Y.; Lyke-Ho-Gland, H. Conventionalization, bifurcation, and quality of life: Certified and non-certified organic farmers in Texas. J. Rural. Soc. Sci. 2008, 23, 208-234.

31. Darnhofer, I.; Lindenthal, T.; Bartel-Kratochvil, R.; Zollitsch, W. Conventionalisation of organic farming practices: From structural criteria towards an assessment based on organic principles. A review. Agron. Sustain. Dev. 2010, 30, 67-81. [CrossRef]

32. Lockie, S.; Halpin, D. The 'conventionalisation' thesis reconsidered: Structural and ideological transformation of Australian organic agriculture. Sociol. Ruralis 2005, 45, 284-307. [CrossRef]

33. Wilkinson, J. Mercados, Redes E Valores: O Novo Mundo da Agricultura Familiar; Editora da UFRGS: Porto Alegre, Brazil, 2008.

34. Niederle, P.A. Políticas de valor nos mercados alimentares: Movimentos sociais econômicos e a reconstrução das trajetórias sociais dos alimentos agroecológicos. Século XXI: Rev. Ciências Sociais 2014, 4, 162-189. [CrossRef]

35. Van der Ploeg, J.D. Camponeses e Impérios Alimentares; lutas por autonomia e sustentabilidade na era da globalicação; UFRGS Editora: Porto Alegre, Brazil, 2008.

36. Best, H. Organic agriculture and the conventionalization hypothesis: A case study from West Germany. Agric. Hum. Values 2008, 25, 95-106. [CrossRef]

37. Oelofse, M.; Høgh-Jensen, H.; Abreu, L.S.; Almeida, G.F.; El-Araby, A.; Hui, Q.Y.; Sultan, T.; de Neergaard, A. Organic farm conventionalisation and farmer practices in China, Brazil and Egypt. Agron. Sustain. Dev. 2011, 31. [CrossRef] 
38. Guivant, J.S. Os supermercados na oferta de alimentos orgânicos: Apelando ao estilo de vida ego-trip. Ambiente Soc. 2003, 6, 63-81. [CrossRef]

39. Oosterveer, P.J.M.; Guivant, J.S.; Spaargaren, G. Alimentos verdes em supermercados globalizados: Uma agenda teórico-metodológica. In Novas Práticas Alimentares. No Mercado Global; Guivant, J.S., Spaargaren, G., Rial, C., Eds.; Editoria UFSC: Florianópolis, Brazil, 2010; pp. 15-58.

40. Da Trindade, V.M.; Rover, O.J.; Medeiros, M. Circuitos (não tão) curtos de comercialização e a promoção de princípios agroecológicos: Um estudo de caso na região da grande Florianópolis. Desenvolv. Meio Ambiente 2017, 42, 370-384.

41. Guptill, A. Exploring the conventionalization of organic dairy: Trends and counter-trends in upstate New York. Agric. Hum. Values 2009, 26, 29-42. [CrossRef]

42. Yin, R.K. Estudo de Caso-: Planejamento e Métodos; Bookman Editora: Porto Alegre, Brazil, 2015.

43. National Census on Agriculture. 2010. Available online: http://dati-censimentoagricoltura.istat.it/Index.aspx (accessed on 10 May 2016).

44. Cadastro Nacional de Produtores Orgânicos. Available online: https://www.gov.br/agricultura/pt-br/ assuntos/sustentabilidade/organicos/cadastro-nacional-produtores-organicos (accessed on 10 May 2017).

45. Quivy, R.; van Campenhoudt, L. Manual de Investigação Em Ciências Sociais, 2nd Edição; Gradiva: Lisboa, Portugal, 1992.

46. Rover, O.J. O método científico em Ciências Sociais: Dos documentos, questionários e entrevistas à análise de enunciados. Rev. Grifos 2012, 21, 13-28. [CrossRef]

47. Bardin, L. Análise de Conteúdo; Edições 70: Lisboa, Portugal, 2000.

48. Renting, H.; Marsden, T.K.; Banks, J. Understanding alternative food networks: Exploring the role of short food supply chains in rural development. Environ. Plann. A 2003, 35, 393-411. [CrossRef]

49. Darolt, M.R.; Lamine, C.; Brandemburg, A. A diversidade dos circuitos curtos de alimentos ecológicos: Ensinamentos do caso brasileiro e francês. Rev. Agric. 2013, 10, 8-13.

50. Darolt, M.R.; Lamine, C.; Brandenburg, A.; Alencar, M.D.C.F.; Abreu, L.S. Redes alimentares alternativas e novas relações produção-consumo na França e no Brasil. Ambiente Soc. 2016, 19, 1-22. [CrossRef]

51. De Assis, R.L.D.; Romeiro, A.R. O processo de conversão de sistemas de produção de hortaliças convencionais para orgânicos. Rev. Adm. Pública. 2007, 41, 863-885. [CrossRef]

52. Corsi, S.; Mazzocchi, C. Alternative Food Networks (AFNs): Determinants for consumer and farmer participation in Lombardy, Italy. Agric. Econ. 2019, 65, 259-269. [CrossRef]

53. Migliore, G.; Schifani, G.; Romeo, P.; Hashem, S.; Cembalo, L. Are farmers in alternative food networks social entrepreneurs? Evidence from a behavioral approach. J. Agric. Environ. Ethics. 2015, 28, 885-902. [CrossRef]

54. Herzog, F.; Balázs, K.; Dennis, P.; Friedel, J.; Geijzendorffer, I.; Jeanneret, P.; Kainz, M.; Pointereau, P. Biodiversity Indicators for European Farming Systems: A Guidebook; Forschungsanstalt Agroscope Reckenholz-Tänikon ART Reckenholz: Zürich, Swiss, 2012.

55. Spearman, C.E. The proof and measurement of association between two things. Am. J. Psychol. 1904, 15, 72-101. [CrossRef]

56. Hill, S.B.; MacRae, R.J. Conceptual framework for the transition from conventional to sustainable agriculture. J. Sustain. Agric. 1996, 7, 81-87. [CrossRef]

57. Meynard, J.; Charrier, F.; Fares, M.; Le Bail, M.; Magrini, M.; Charlier, A.; Messéan, A. Socio-technical lock-in hinders crop diversification in France. Agron. Sustain. Dev. 2018, 38, 54. [CrossRef]

(C) 2020 by the authors. Licensee MDPI, Basel, Switzerland. This article is an open access article distributed under the terms and conditions of the Creative Commons Attribution (CC BY) license (http://creativecommons.org/licenses/by/4.0/). 